\title{
3D Petrophysical Modelling Of Queen Field, Onshore Niger Delta, Nigeria
}

\author{
${ }^{1}$ EZE, C; ${ }^{2}$ EMUJAKPORUE, G; *3 OKUJAGU, DC \\ ${ }^{1}$ Center for Petroleum Geosciences, ${ }^{2}$ Department of Physics, ${ }^{* 3}$ Department of Geology, University of Port Harcourt, PMB 5323, Port \\ Harcourt, Nigeria \\ "Corresponding Author Email: diepiriye.okujagu@uniport.edu.ng; Other Authors Email: chindaezekwesili@gmail.com, \\ godwin.emujakporue@uniport.edu.ng
}

\begin{abstract}
Petrophysical-Modelling is indispensable in upstream Projects, considering the high cost, risks and uncertainties associated with this sector. Petrophysical qualities for Queen Field was modeled using Information obtained and analyzed from well-logs and 3-D Seismic data. Coarse-grain, Medium- grain and fine-grain Sands as well as Shale were all delineated by GR log. Results of petrophysical evaluation conducted on seven reservoir intervals correlated across the field showed that; Shale volume was below $35 \%$, Total Porosity are $>20 \%$ Effective Porosity are $>15 \%$ Permeability is $>380.00 \mathrm{mD}$ all of this conforms to excellent reservoir quantity. Seismic interpretation showed the presence of synthetic and antithetic faults. Two horizons were mapped on seismic data and utilized for modeling. These models were the framework for facies and petrophysical properties distribution. Facies models were generated using sequential indicator simulation while petrophysical properties were generated using sequential gaussian simulation algorithm. A comparison was further done between facies constrained and non-facies constrained models. It was found that for Porosity, Permeability, Water of Saturation and Shale Volume Models not constrained to facies all showed overestimated Models, in addition Stochastic STOIIP not constrained to facies gave an Over Estimated P50 value for Surface I and O Reservoir Interval as 624.028M, 76.28MM, when compared to Stochastic Hydrocarbon STOIIP when constrained to facies that showed Stochastic P50 value of 513,247 and 67.04MM for surface I and O and Deterministic STOIIP of $742.90 \mathrm{M}$ and $87.88 \mathrm{MM}$. This study validates the practice of constraining Petrophysical model to facies available on the field as the best practice.
\end{abstract}

\section{DOI: https://dx.doi.org/10.4314/jasem.v24i11.14}

Copyright: Copyright (C) 2020 Eze et al. This is an open access article distributed under the Creative Commons Attribution License (CCL), which permits unrestricted use, distribution, and reproduction in any medium, provided the original work is properly cited.

Dates: Received: 25 January 2020; Revised: 05 November 2020; Accepted: 14 November 2020

Keywords: Queen Field, Onshore, Niger Delta, 3D Petrophysical.

The Petroleum industry is saddled with the continuous growth in demand for hydrocarbon and subsequent intensity on oil/gas exploration to meet energy demands. Frontier basins/regions like the cold seas of the Artic and deep offshore are now explored actively. The need to hasten the time needed for initial appraisal and reduction of uncertainties, risks and difficulty associated in exploring for the hydrocarbon, and also to cut down cost of exploration cannot be over emphasized and has resulted in the search for a comprehensive method to characterize Petroleum Fields. One important method, is the use of petrophysics in reservoir characterization and modelling for optimal production rate and sweep (Emujakporue, 2017). Petrophysical properties are used to rank projects for investment decisions to be made on economically viable projects. Reservoir characterization, generates Petrophysical models that allow for a more precise prediction of future performance and appraisal of reserves (Morton et al.,2002). The Niger-Delta, which is our study location has heterogeneous reservoirs thus a critical petrophysical analysis and model development is required to ensure optimal enhancement of oil recovery using a 3D petrophysical model. This study is aimed at building 3-dimensional Petrophysical models of the Queen Field with an objective to characterize, evaluate and estimate STOIIP, for informed decision making. This study adopts the geology and tectonic settings of the Niger Delta according to (John et al. 2019). Considering how important petrophysical studies is to exploration and developmental decisions and future interventions in hydrocarbon production from a field, several studies have been carried out to Model petrophysical properties and quantify hydrocarbon volumes. (Emujakporue, 2017) performed a petrophysical properties distributions modelling of an onshore field in Niger Delta. In his research 3D grids represented reservoirs geometry and petrophysical properties such as Porosity, $\mathrm{S}_{\mathrm{W}}$, NTG ratio, facies and Perm $(\mathrm{mD})$ were populated on the grids. The work aimed on generating 3D dimension model characterizing and evaluating sands. Two sands were delineated from the logs available and the porosity values found in the sands ranged from 0.061- 0.30 average of 0.185 , Perm $(\mathrm{mD})$ values $110-2394 \mathrm{md}$, 
SW from 0.23-0.57 with an average of 0.4, NTG from 0.44-0.87 with an average of about 0.61. All the properties modelled showed uniform distribution in the reservoirs, and it was inferred with help from the model that the onshore Niger-Delta field's central portion was very good and production well was recommended. (Onyekuryu et al., 2017) analyzed Olu field onshore Niger Delta. In the research both structural and stratigraphic structures where delineated. 14 faults were mapped the faults conformed to synthetic and regular antithetic faults. 4 horizon, $\mathrm{H} 1, \mathrm{H} 2, \mathrm{H} 3, \mathrm{H} 4$ and 3 hydrocarbons prone sand where found.

Porosity values ranged from 0.14 to 0.28 this meets economic requirements and suitable for more drilling and development of the field. (Nwankwo et al., 2014) carried out petrophysical modelling of a siliciclastic hydrocarbon Sand in Niger-delta. The approach used was an integrated seismic and well $\log$ data interpretation. Two reservoirs hydraulic zones (Sand D and F) were mapped using petrel 2014 software. The average estimated porosity was $22.4 \%-22.02 \%$, Perm 1444md - 1375md NTG 72.3-84.9; and SW 39.5 -39.4 .

Values where favorable to support hydrocarbon production in the field. Evaluation of Uzek well petrophysical characteristics was done by (Adaeze et al., 2012). Porosity, Vsh sand parameters amongst more, where the main aim of the research. Sands I, P, $\mathrm{Q}$, $\mathrm{R}$ which were hydrocarbon reservoirs were delineated. Average Perm (mD) values obtained from Sands was values above $100 \mathrm{md}$. Porosity values ranged from 0.2 to 0.3 conformance to well sorted siliciclastic reservoirs having marginal cementation was inferred.

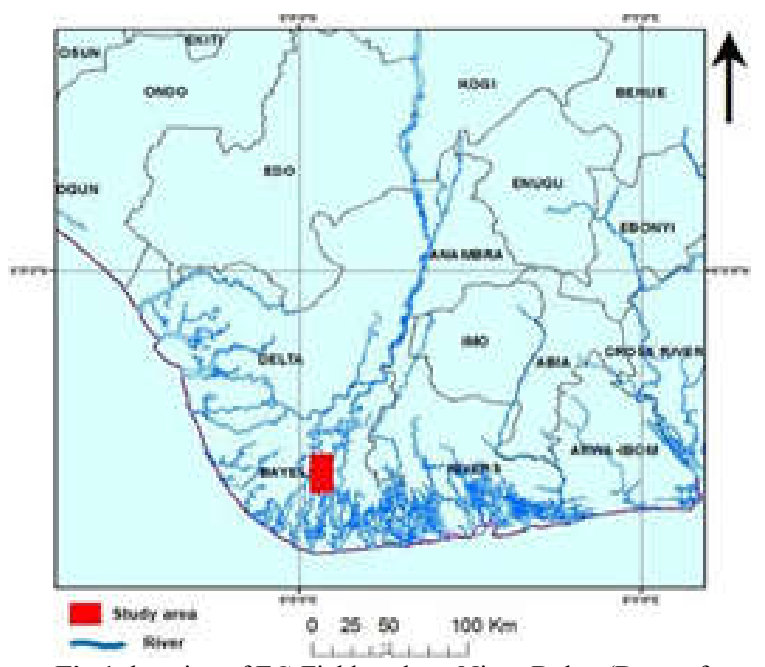

Fig 1: location of EC-Field onshore Niger-Delta. (Dept. of Petroleum Resource, NIG, 2005)
It was concluded from the research that Uzek well reservoirs are favorable for hydrocarbon production. (Ameloko and Oweseni, 2015) carried out an evaluation on X field. Sands A, B and C delineated had hydrocarbon saturation ranging from $74.3 \%$ to $91 \%$. Petrophysical parameters in the X field was estimated and was discovered that the structural trap styles were discovered good for hydrocarbon accumulation. (Amigun and Odole, 2013) used Petrophysical properties to evaluate wells for Seyi oilfield Niger Delta. Petrophysical parameters denoted across the field was porosity with values ranging from 0.22 to 0.31 , Permeability had values ranging from 881.58 to 14425.01 and average hydrocarbon saturation of $41.44 \%, 20.29 \%, 30.82 \%, 37.92 \%, 51.20 \%, 91.97 \%$, $85.11 \%$ across the 7 Reservoirs (A, B, C, D, E, F) Delineated. Movable Hydrocarbon index of 0.05 to 0.75 was noted across the field. The field was found to have a good hydrocarbon production condition.

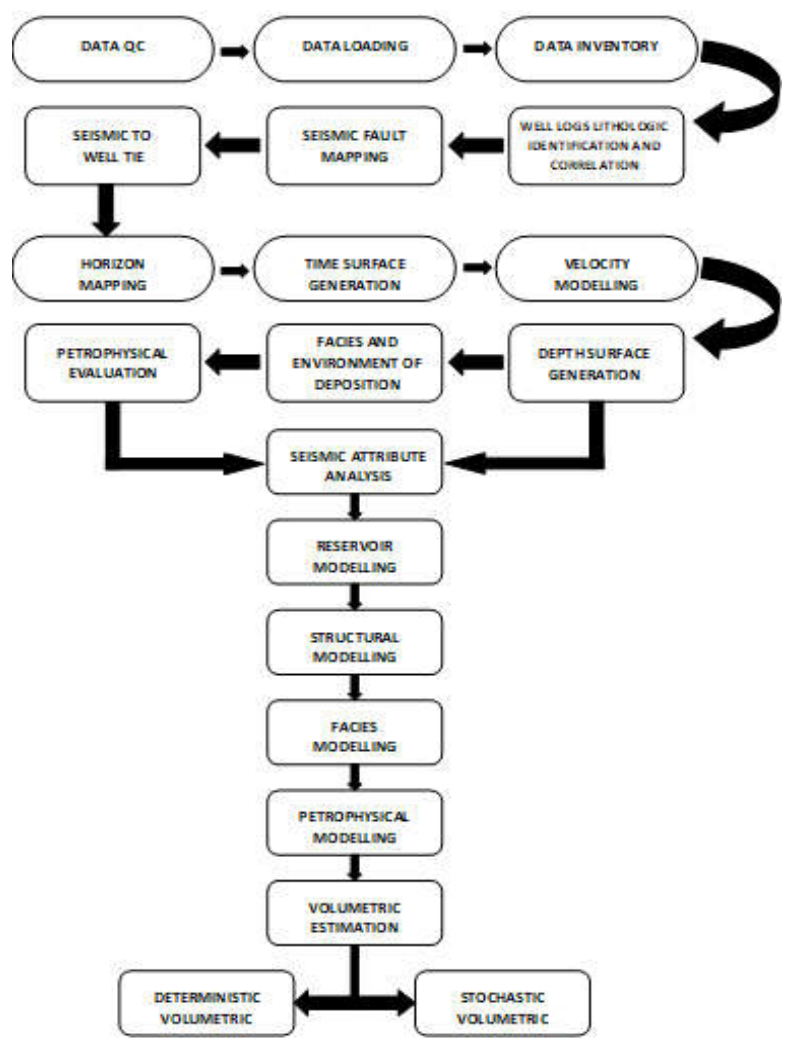

Fig 2: Workflow utilized for the execution of this study

\section{MATERIALS AND METHOD}

Seismic and well logs information were used in this research to build up the basic, stratigraphic and petrophysical properties of the Queen field, using Petrel software following the method of Philip 2013. Table 1 demonstrates the suite of well log Data for the Queen Field. 
Study Area: Queen Field is located at eastern region on the coastal-swamp depobelt within Onshore Niger- Delta, operated by Shell Petroleum Development Company (SPDC). The field is defined by its seismic data coverage and extends from latitude $4^{\circ} 35^{\prime} 00^{\prime \prime} \mathrm{N}$ to $4^{\circ} 39^{\prime} 00^{\prime \prime} \mathrm{N}$ and longitude $6^{\circ} 16^{\prime} 00^{\prime \prime} \mathrm{E}$ to $6^{\circ} 20^{\prime} 00^{\prime \prime} \mathrm{E}$ with an area of $43.84 \mathrm{~km}^{2}$ Fig. 1 shows the location of Queen Field in Niger Delta Nigeria.

\section{RESULTS AND DISCUSSION}

Well Log Correlation: Litho-stratigraphic correlation was used to delineate sands. Different lithologies was identified using the GR log. The identified lithologies where sand and shale, colour filling was applied yellow colour was used to denote sands while dark grey colour indicated shale. Seven sand zones were mapped I - O and where correlated across the field

Fig 3 shows lithostratigraphic correlation across the four wells $\mathrm{X}, \mathrm{Y}, \mathrm{Z}$ and $\mathrm{V}$ available in the field of study. The analysis on RHOB/NPHI plot and RES logs plot showed 6 Reservoirs Hydrocarbon Bearing among the seven occurring sands and the one sands left was water bearing

\begin{tabular}{lllllllllll}
\multicolumn{10}{c}{ Table 1: well log data for DOVE field } \\
\hline Well Name & Well & Log & Well & Checkshot & GR & CALI & DI & NPHI & RHOB & RES \\
& Header & Header & Deviation & & & & & & & \\
\hline QUEEN-X & YES & YES & YES & NO & YES & YES & YES & YES & YES & YES \\
QUEEN-Y & YES & YES & YES & NO & YES & YES & YES & YES & YES & YES \\
QUEEN-Z & YES & YES & YES & NO & YES & YES & YES & YES & YES & YES \\
\hline QUEEN-V & YES & YES & YES & YES & YES & YES & YES & YES & YES & YES \\
\hline
\end{tabular}

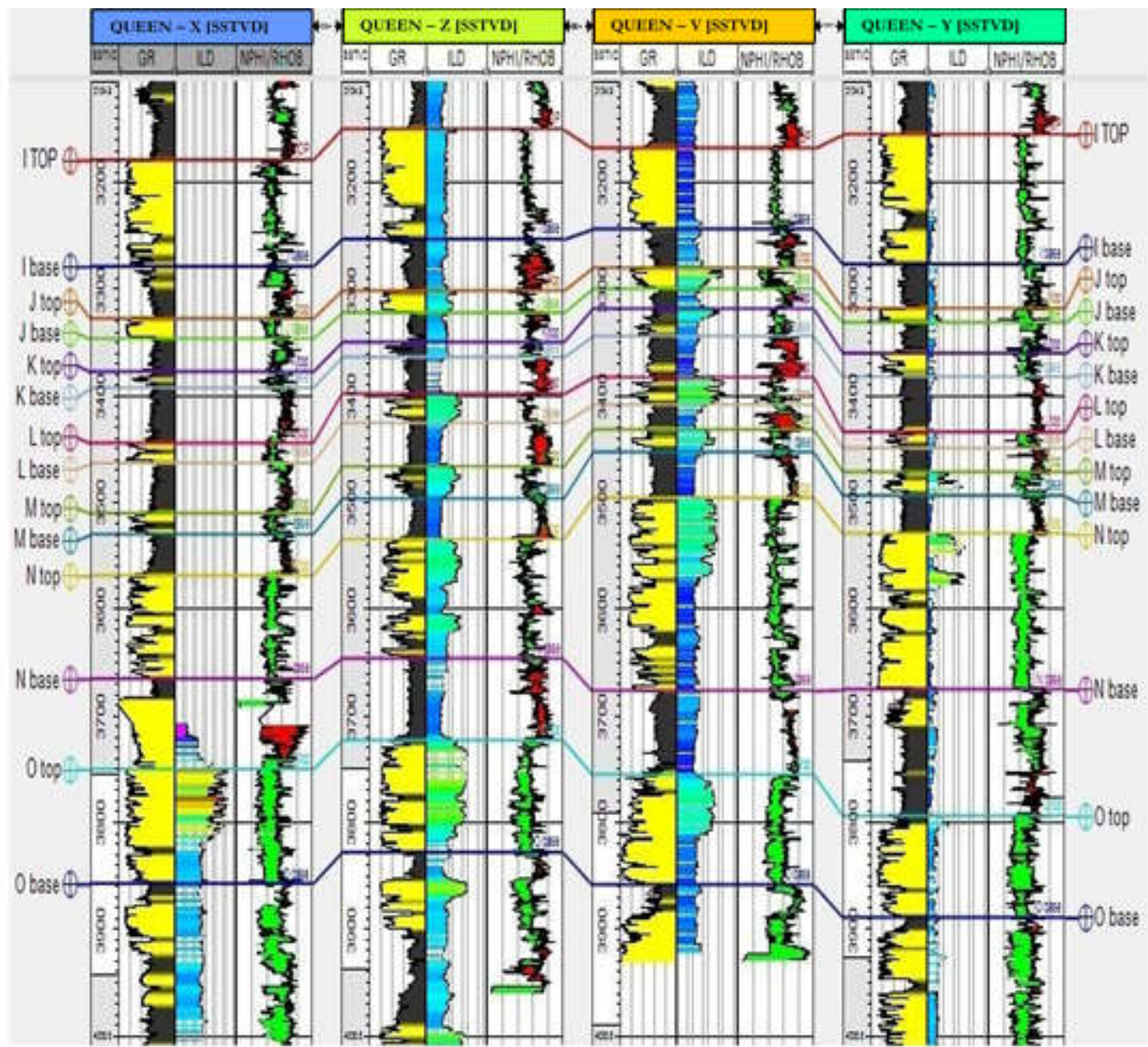

Fig 3: Litho-correlation of the 4 wells in "EC"-Field with Six Hydrocarbon bearing Sand 
Fault Modelling /Interpretation: Fault modelling was accomplished using the fault polygons as input. The faults were modelled using the listric pillar type because Niger Delta faults are listric. The fault pillar increment used was 300 and the default pillar height was 300. Antithetic and Synthetic faults where noticed in the study field figure 4 and 5 shows inline 5636 with presence of both anthetic and synthetic fault, mapped horizon and modelled fault.

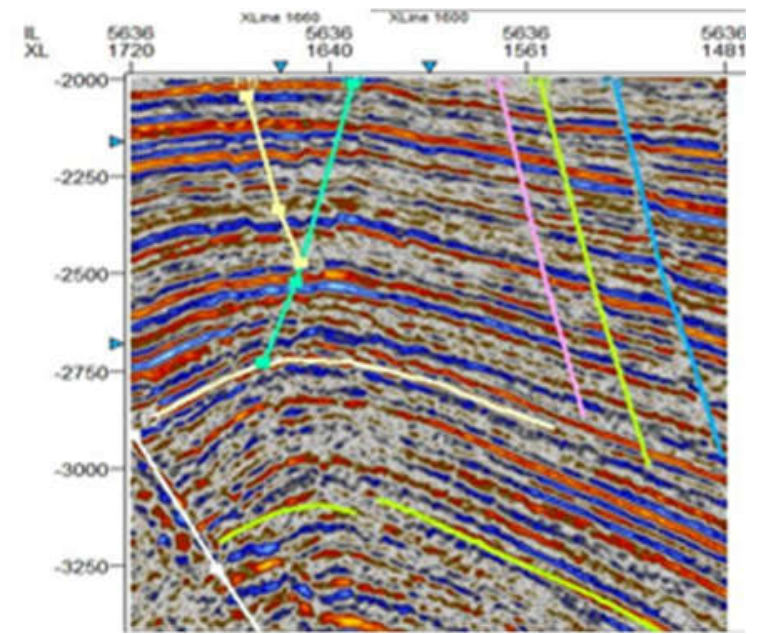

Fig 4: Anthetic and Synthetic faults on inline 5636

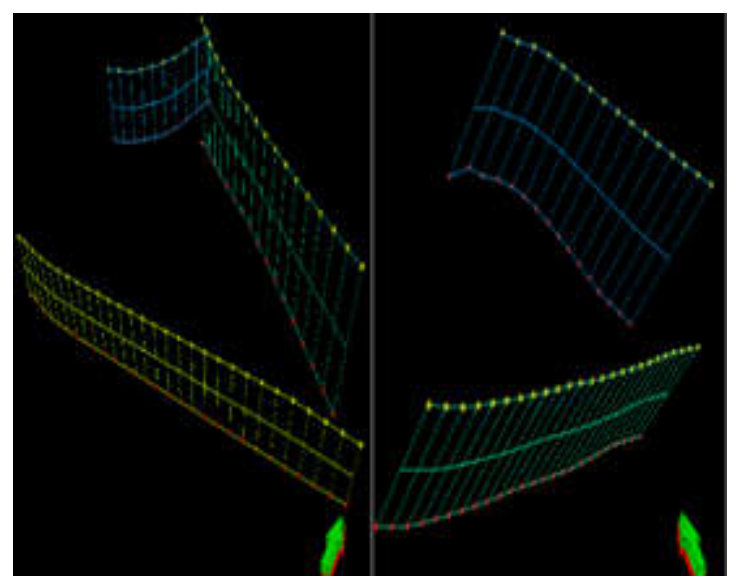

Fig 5: Modelled Fault

Seismic To Well Tie: Well Y Checkshot was utilized, seismic to well tie is important to enable the well to be seen on seismic and to enable horizon to be mapped on the seismic data. Fig 6 shows the synthetic seismogram with perfect match.

Pillar Gridding: The pillar gridding process was conducted in order to build a structural framework for the reservoir. The process was responsible for generating the grid dimensions that will hold the modelled properties. Figure 7 and 8 shows Seeded and surface grid for Reservoir I and Reservoir O

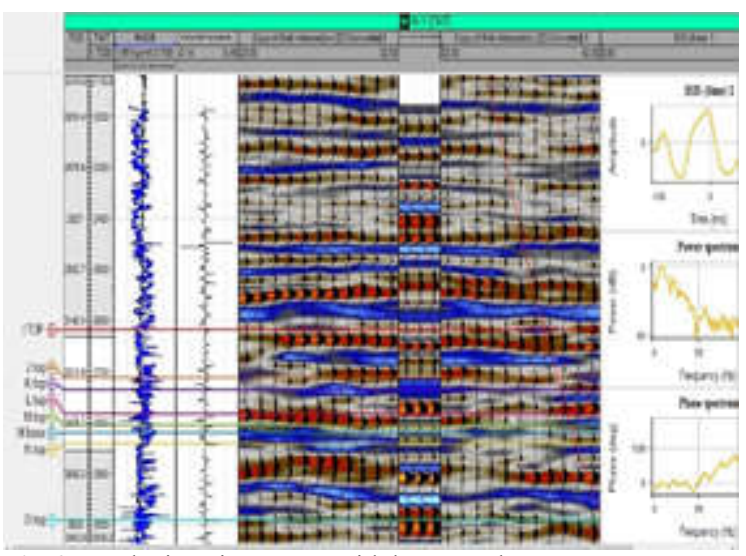

Fig 6: Synthetic Seismogram with best match

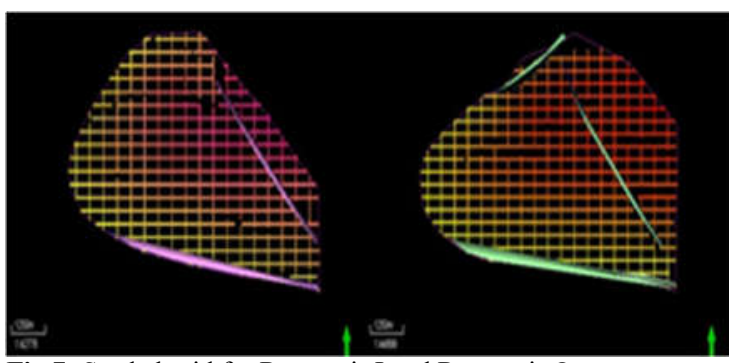

Fig 7: Seeded grid for Reservoir I and Reservoir O

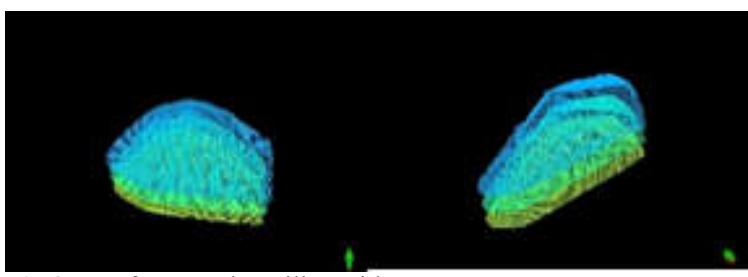

Fig 8: Surface I and O pillar grids
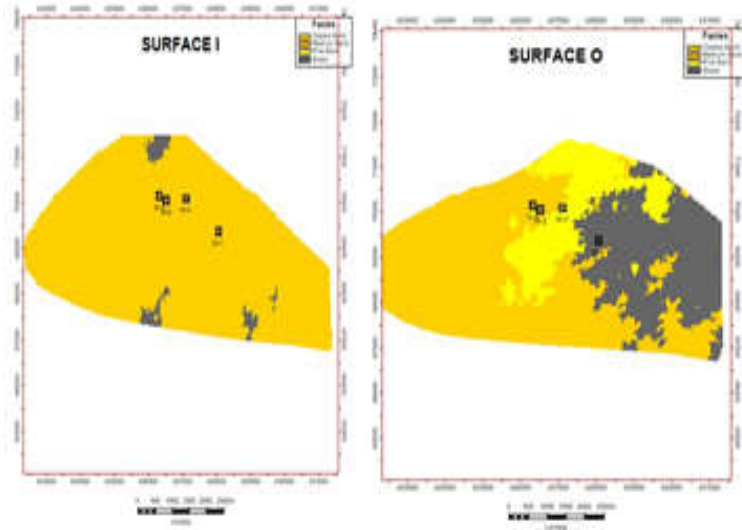

Fig 9: Facie Modelling for Surface I and Facie modelling for Surface $\mathrm{O}$

Facies Modelling: Sequential Indicator Simulation (SIS) technique was used for the generation of the Facies model in this research work. SIS is a stochastic simulation method that populates facies between observations, and relies on indicator kriging 
to obtain some facies continuity beyond just nearby cells. Figure 9 shows Facie Modelling for Surface I and Facie modelling for Surface O. Petrophysical

Modelling: In this research work petrophysical property distribution of the values was done stochastically using Sequential Gaussian Simulation (SGS). The petrophysical models (Shale Volume, Porosity, Permeability and Water of Saturation) were generated using the upscaled logs. The petrophysical models were conditioned by the facies models. The spherical variogram was used to distribute properties across the 3-D grid. Furthermore, for this Research work to compare the outcomes Petrophysical models were also carried out not conditioned to facies model.
Upscaling Well Logs: The facies and petrophysical logs generated from empirical equations were upscaled to be used for modelling. This process was necessary in order to decrease the complexity of the model building process through a process of Blocking. The upscaled logs were coarser when compared with the actual petrophysical and facies logs. The results of petrophysical evaluation of Queen Field is shown in tables 2 to 9 . Shale volume was below $35 \%$ in the reservoirs Total Porosity are $>20 \%$ Effective Porosity are $>15 \%$ Permeability is $>380.00 \mathrm{mD}$ all of this conforms to excellent reservoir quantity. Reservoir Intervals I and $\mathrm{O}$ was studied they are both hydrocarbons bearing.

Table 2 Results from well-Z

\begin{tabular}{|c|c|c|c|c|c|c|c|c|c|c|c|}
\hline ZONE & $\begin{array}{l}\text { TOP } \\
\text { (MD) }\end{array}$ & $\begin{array}{l}\text { BASE } \\
\text { (MD) }\end{array}$ & OWC & $\begin{array}{l}\text { GROSS } \\
\text { THICKNESS } \\
\text { (MD) }\end{array}$ & $\begin{array}{l}\text { NET } \\
\text { THICKNESS } \\
\text { (MD) }\end{array}$ & $\begin{array}{l}\text { PORO } \\
\text { E }\end{array}$ & SW & $\begin{array}{l}\text { VSH( } \% \\
)\end{array}$ & $\begin{array}{l}\text { NTG } \\
\text { (FRAC) }\end{array}$ & FLUIDS & $\begin{array}{l}\text { PERM } \\
\text { (MD) }\end{array}$ \\
\hline I & 3169 & 3270 & $3170 \mathrm{M}$ & 101 & 86.86 & 0.2 & 0.78 & 0.14 & 86 & $\begin{array}{l}\text { OIL/ } \\
\text { WATER }\end{array}$ & 537.88 \\
\hline $\mathrm{J}$ & 3320 & 3340 & ODT & 20 & 18.4 & 0.23 & 0.55 & 0.08 & 92 & OIL & 1255.2 \\
\hline K & 3370 & 3380 & WUT & 10 & 7.6 & 0.14 & 0.98 & 0.24 & 76 & WATER & 528.7 \\
\hline $\mathrm{L}$ & 3420 & 3445 & $3440 \mathrm{M}$ & 25 & 18 & 0.17 & 0.37 & 0.28 & 72 & $\begin{array}{l}\text { OIL/ } \\
\text { WATER }\end{array}$ & 1139.22 \\
\hline M & 3488 & 3518 & $3500 \mathrm{M}$ & 30 & 20.7 & 0.14 & 0.46 & 0.31 & 69 & $\begin{array}{l}\text { OIL/ } \\
\text { WATER }\end{array}$ & 790.83 \\
\hline $\mathrm{N}$ & 3553 & 3662 & $3640 \mathrm{M}$ & 109 & 86.11 & 0.17 & 0.55 & 0.21 & 79 & $\begin{array}{l}\text { OIL/ } \\
\text { WATER }\end{array}$ & 899.7 \\
\hline $\mathrm{O}$ & 3761 & 3844 & $3830 \mathrm{M}$ & 83 & 73.87 & 0.2 & 0.3 & 0.11 & 89 & $\begin{array}{l}\text { OIL/ } \\
\text { WATER }\end{array}$ & 1210.14 \\
\hline \multicolumn{5}{|c|}{$\begin{array}{l}\text { OWC-OIL WATER CONTACT; ODT-OIL DOWN } \\
\text { NTG-NET TO GROSS; PERM- PERMEABILITY }\end{array}$} & \multicolumn{3}{|c|}{ TO; WUT-WATER UP TO } & Shale & OLUME; & \multicolumn{2}{|c|}{$\begin{array}{l}\text { PORO E- EFFECTIVE } \\
\text { POROSITY }\end{array}$} \\
\hline
\end{tabular}

\begin{tabular}{|c|c|c|c|c|c|c|c|c|c|c|c|}
\hline ZONE & $\begin{array}{l}\text { TOP } \\
\text { (MD) }\end{array}$ & $\begin{array}{l}\text { BASE } \\
\text { (MD) }\end{array}$ & OWC & $\begin{array}{l}\text { GROSS } \\
\text { THICKNESS } \\
\text { (MD) }\end{array}$ & $\begin{array}{l}\text { NET } \\
\text { THICKNESS } \\
\text { (MD) }\end{array}$ & PORO E & SW & $\begin{array}{l}\text { VSH } \\
(\%)\end{array}$ & $\begin{array}{l}\text { NTG } \\
\text { (FRAC) }\end{array}$ & FLUIDS & $\begin{array}{l}\text { PERM } \\
\text { (MD) }\end{array}$ \\
\hline I & 3165 & 3240 & WUT & 75 & 63.75 & 0.19 & 0.94 & 0.15 & 85 & WATER & 579.9 \\
\hline $\mathrm{J}$ & 3276 & 3296 & ODT & 20 & 17.8 & 0.18 & 0.16 & 0.11 & 89 & OIL & 1163.59 \\
\hline K & 3315 & 3343 & $3323 \mathrm{M}$ & 28 & 22.12 & 0.14 & 0.94 & 0.21 & 79 & OIL/WATER & 450.04 \\
\hline $\mathrm{L}$ & 3380 & 3406 & ODT & 26 & 20.02 & 0.9 & 0.26 & 0.23 & 77 & OIL & 1103.23 \\
\hline M & 3428 & 3449 & ODT & 21 & 14.91 & 0.17 & 0.19 & 0.29 & 71 & OIL & 655.6 \\
\hline $\mathrm{N}$ & 3498 & 3678 & $3566 \mathrm{M}$ & 180 & 147.6 & 0.15 & 0.4 & 0.18 & 82 & OIL/WATER & 930 \\
\hline $\mathrm{O}$ & 3750 & 3856 & $3810 \mathrm{M}$ & 106 & 94.34 & 0.16 & 0.46 & 0.11 & 89 & OIL/WATER & 1345.66 \\
\hline
\end{tabular}

OWC-OIl Water Contact; ODT- OIL doWn to; WUT- WATER UP To; VSh- Shale VoluME; NTG- Net To Gross; PermPermeability; Poro E- Effective Porosity

\begin{tabular}{|c|c|c|c|c|c|c|c|c|c|c|c|}
\hline ZONE & $\begin{array}{l}\text { TOP } \\
\text { (MD) }\end{array}$ & $\begin{array}{l}\text { BASE } \\
\text { (MD) }\end{array}$ & OWC & $\begin{array}{l}\text { GROSS } \\
\text { THICKNESS } \\
\text { (MD) }\end{array}$ & $\begin{array}{l}\text { NET } \\
\text { THICKNESS } \\
\text { (MD) }\end{array}$ & PORO E & SW & $\begin{array}{l}\text { VSH } \\
(\%)\end{array}$ & $\begin{array}{l}\text { NTG } \\
\text { (FRAC) }\end{array}$ & FLUIDS & $\begin{array}{l}\text { PERM } \\
\text { (MD) }\end{array}$ \\
\hline $\mathrm{J}$ & 3340 & 3357 & & 17 & 16.15 & 0.21 & & 0.05 & 95 & - & - \\
\hline K & 3391 & 3401 & & 10 & 7.6 & 0.15 & & 0.24 & 76 & - & - \\
\hline $\mathrm{L}$ & 3460 & 3475 & & 15 & 12.9 & 0.22 & & 0.14 & 86 & - & - \\
\hline M & 3521 & 3538 & & 17 & 14.62 & 0.21 & & 0.14 & 86 & - & - \\
\hline $\mathrm{N}$ & 3580 & 3675 & & 95 & 82.65 & 0.21 & & 0.13 & 87 & - & - \\
\hline $\mathrm{O}$ & 3760 & 3866 & $3831 \mathrm{M}$ & 106 & 97.52 & 0.22 & 0.38 & 0.08 & 92 & OIL & 1190.1 \\
\hline
\end{tabular}

OWC- Oil Water Contact; Vsh- Shale Volume; NTG- Net to Gross; Perm- Permeability; Poro

/WATER 
Table 5 Results of well-Y

\begin{tabular}{|c|c|c|c|c|c|c|c|c|c|c|c|}
\hline ZONE & $\begin{array}{l}\text { Top } \\
\text { (MD) }\end{array}$ & $\begin{array}{l}\text { Base } \\
\text { (MD) }\end{array}$ & OWC & $\begin{array}{l}\text { Gross } \\
\text { thickness } \\
\text { (MD) }\end{array}$ & $\begin{array}{l}\text { Net } \\
\text { Thickness } \\
\text { (MD) }\end{array}$ & $\begin{array}{l}\text { PORO } \\
\text { E }\end{array}$ & SW & $\begin{array}{l}\text { Vsh } \\
\%\end{array}$ & $\begin{array}{l}\text { NTG } \\
\text { (Frac) }\end{array}$ & FLUIDS & $\begin{array}{l}\text { Perm } \\
\text { (mD) }\end{array}$ \\
\hline I & 3180 & 3300 & WUT & 120 & 105.6 & 0.23 & 0.99 & 0.12 & 88 & Water & 45.37 \\
\hline $\mathrm{J}$ & 3346 & 3359 & WUT & 13 & 12.22 & 0.22 & 0.99 & 0.06 & 94 & Water & 307.07 \\
\hline K & 3385 & 3404 & WUT & 19 & 16.53 & 0.2 & 0.99 & 0.13 & 87 & Water & 60.59 \\
\hline $\mathrm{L}$ & 3460 & 3470 & $3465 \mathrm{~m}$ & 10 & 7.5 & 0.16 & 0.89 & 0.25 & 75 & $\begin{array}{l}\text { Oil and } \\
\text { Water }\end{array}$ & 310.88 \\
\hline M & 3500 & 3516 & ODT & 16 & 12.96 & 0.19 & 0.44 & 0.19 & 81 & Oil & 1165.03 \\
\hline $\mathrm{N}$ & 3556 & 3700 & $3606 \mathrm{~m}$ & 144 & 131.04 & 0.22 & 0.8 & 0.09 & 0.91 & $\begin{array}{l}\text { Oil and } \\
\text { Water }\end{array}$ & 446.05 \\
\hline $\mathrm{O}$ & 3828 & 3921 & $3836 \mathrm{~m}$ & 93 & 8.37 & 0.22 & 0.87 & 0.1 & 0.9 & $\begin{array}{l}\text { Oil and } \\
\text { Water }\end{array}$ & 240.18 \\
\hline
\end{tabular}

OWC- Oil Water Contact; WUT- Water up to; Vsh- Shale Volume; NTG- Net to Gross; Perm- Permeability; Poro EEffective Porosity

Table 6 Averaged Results for sands across the four wells of study

\begin{tabular}{crrrrrrr}
\hline ZONE & $\begin{array}{c}\text { Gross thickness } \\
\text { (MD) }\end{array}$ & $\begin{array}{c}\text { Net } \\
\text { Thickness(MD) }\end{array}$ & PORO E & SW & Vs h\% & NTG (Frac) & Perm (mD) \\
\hline Sand I & 97.75 & 82.82 & 0.21 & 0.9 & 0.16 & 88 & 387.71 \\
Sand J & 17.5 & 16.14 & 0.21 & 0.57 & 0.08 & 92.5 & 908.62 \\
Sand K & 16.75 & 13.46 & 0.16 & 0.97 & 0.21 & 79.5 & 346.44 \\
Sand L & 19 & 14.61 & 0.36 & 0.93 & 0.23 & 77.5 & 851.11 \\
Sand M & 21 & 15.8 & 0.18 & 0.36 & 0.23 & 76.8 & 870.5 \\
Sand N & 132 & 111.85 & 0.13 & 0.58 & 0.13 & 62.23 & 758.58 \\
Sand O & 97 & 68.53 & 0.2 & 0.5 & 0.1 & 0.9 & 996.52 \\
\hline
\end{tabular}

Table 7 Average results for Reservoir I and O studied

\begin{tabular}{lllllll}
\hline ZONE & $\begin{array}{l}\text { Gross } \\
\text { Thickness } \\
\text { (MD) }\end{array}$ & $\begin{array}{l}\text { Net } \\
\text { Thickness } \\
\text { (MD) }\end{array}$ & PORO E & SW & Vs h\% & $\begin{array}{l}\text { Perm } \\
\text { (mD) }\end{array}$ \\
\hline I & 97.75 & 82.82 & 0.21 & 0.9 & 0.16 & 387.71 \\
O & 97 & 68.53 & 0.2 & 0.5 & 0.1 & 996.52 \\
\hline
\end{tabular}

Table 8 Results from deterministic hydrocarbon volume estimation for selected reservoir

\begin{tabular}{llll} 
Zones & HC Area $\left[\mathbf{m}^{2}\right]$ & Bulk volume $\left[\mathbf{m}^{2}\right]$ & STOIIP [STB] \\
\hline Reservoir I & $455,655.07$ & $6,132,630.00$ & $742.90 \mathrm{M}$ \\
\hline Reservoir O & $6,324,934.05$ & $173,109,740.00$ & $87.88 \mathrm{MM}$
\end{tabular}

Table 9 Results from stochastic hydrocarbon volume estimation for selected reservoir Constrained

\begin{tabular}{llllll} 
P value & STOIIP $(\mathbf{S T B})$ & $\mathbf{H C P V}\left(\mathbf{m}^{\mathbf{3}}\right)$ & Pore volume $\left(\mathbf{m}^{\mathbf{3}}\right)$ & Net Volume $\left(\mathbf{m}^{\mathbf{3}}\right)$ & Bulk volume $\left(\mathbf{m}^{\mathbf{3}}\right)$ \\
\hline & & \multicolumn{5}{c}{ Reservoir I } \\
P10 & $424.257 \mathrm{M}$ & $86,461.62$ & $1,280,821.60$ & $5,170,271.89$ & $5,266,402.38$ \\
P50 & $513.247 \mathrm{M}$ & $104,429.95$ & $1,291,361.69$ & $5,240,794.06$ & $5,266,402.38$ \\
P90 & $680.902 \mathrm{M}$ & $138,281.72$ & $1,309,065.30$ & $5,244,328.71$ & $5,266,402.38$ \\
& & & Reservoir O & & \\
P10 & $63.09 \mathrm{MM}$ & $13,334,532.39$ & $113,884,730.04$ & $153,950,139.04$ & $187,034,441.94$ \\
P50 & $67.04 \mathrm{MM}$ & $14,132,506.85$ & $119,163,766.40$ & $156,382,757.50$ & $187,034,441.94$ \\
\hline P90 & $80.26 \mathrm{MM}$ & $17,004,528.06$ & $119,189,518.98$ & $157,076,056.33$ & $187,034,441.94$
\end{tabular}

Table 10 Results for models stochastic not constrained to Facie

\begin{tabular}{llllll} 
P value & STOIIP $(\mathbf{S T B})$ & HCPV $\left(\mathbf{m}^{\mathbf{3}}\right)$ & Pore volume $\left(\mathbf{m}^{\mathbf{3}}\right)$ & Net Volume $\left(\mathbf{m}^{\mathbf{3}}\right)$ & Bulk volume $\left(\mathbf{m}^{3}\right)$ \\
\hline & & & Reservoir I & & \\
P10 & $442.526 \mathrm{M}$ & $89,352.23$ & $1,224,090.31$ & $5,070,212.53$ & $5,265,402.38$ \\
P50 & $624.028 \mathrm{M}$ & $112,600.11$ & $1,281,673.73$ & $5,200,283.02$ & $5,265,402.38$ \\
P90 & $928.028 \mathrm{M}$ & $187,467.40$ & $1,293,431.99$ & $5,246,391.51$ & $5,265,402.38$ \\
& & Reservoir O & & \\
P10 & $70.04 \mathrm{MM}$ & $14,222,242.13$ & $30,126,574.38$ & $157,030,368.53$ & $187,034,441.94$ \\
P50 & $76.28 \mathrm{MM}$ & $15,403,048.01$ & $32,251.733 .51$ & $162,430,158.02$ & $187,034,441.94$ \\
\hline P90 & $87.53 \mathrm{MM}$ & $17,674,538.91$ & $33,807,891.28$ & $169,785,625.22$ & $187,034,441.94$
\end{tabular}


Deterministic and Stochastic Hydrocarbon STOIIP shows $742.90 \mathrm{M}$ and $87.88 \mathrm{MM}$ for Surface I and O Deterministic and P50 value showed 513,247 and 67.04MM for surface I and $\mathrm{O}$, also further more Stochastic STOIIP not constrained to facies gave P50 value for Surface I and $\mathrm{O}$ as $624.028 \mathrm{M}$, 76.28MM, this over estimates STOIIP.

Conclusion: This study utilized both deterministic map based and stochastic model based for hydrocarbon volume estimation. Petrophysical properties of the two surfaces, I and $\mathrm{O}$ where modelled not constrained to facie and also constrained to facie. The results showed that it is best to model Petrophysical properties constrained to facie because the Petrophysical model not constrained to facie gave an over estimated value for hydrocarbon volume estimation.

\section{REFERENCE}

Adaeze, IU; Samuel, OO; Cajetan, JI (2012). Petrophysical evaluation of Uzek well using well $\log$ and core data, Offshore Depobelt, Niger Delta, Nigeria. Adv. Appl. Sci. Res. 3(5), 29662991.

Ameloko, A; and Owoseni, A. (2015). Hydrocarbon reservoir evaluation of X-field, Niger Delta using seismicand petrophysical data. Inter. J. Innovate. Sci. Res. 15(1), 193 - 201.
Amigun, JO; and Odole, AO (2013). Petrophysical Properties Evaluation for Reservoir Characterization of SEYI Oil Field (Niger-Delta). Inter. J. Innovate. Appl. Stud., 3, 765-773.

Emujaporue, GO (2017). Petrophysical properties distribution modeling of an onshore field, Niger Delta Nigeria. Curr. Res. Geosci. 7(1):14-24

John, PT; Emujakporue, G Okujagu, DC (2019). Spatial Variation of Reservoir Properties in Onshore Dove Field of the Niger Delta Region, Nigeria. J. Appl. Sci. Environ. Manage. 23(12): 2125-2130

Nwankwo, CN; Anyanwu, J; Ugwu, SA (2014). Integration of seismic and well log data for petrophysical modeling of sandstone hydrocarbon reservoir in Niger Delta. Sci. Afr. 13(1):186-199

Samuel, O; Oluoma, CF; Adikwu, SO; Okoro, EM; Obaje, EC (2017). 3D Seismic Interpretation and Petrophysical Analysis of "Olu Field" Onshore Niger Delta. Inter. J. Geophysics. Geochemistry. 4(6): 73-82. 